\title{
NMDA and AMPA Receptors: Development and Status Epilepticus
}

\section{E. SZCZUROWSKA ${ }^{1}$, P. MARE $\check{S}^{1}$}

${ }^{1}$ Department of Developmental Epileptology, Institute of Physiology Academy of Sciences of the Czech Republic, Prague, Czech Republic

Received July 1, 2013

Accepted September 17, 2013

\section{Summary}

Glutamate is the main excitatory neurotransmitter in the brain and ionotropic glutamate receptors mediate the majority of excitatory neurotransmission (Dingeldine et al. 1999). The high level of glutamatergic excitation allows the neonatal brain (the $2^{\text {nd }}$ postnatal week in rat) to develop quickly but it also makes it highly prone to age-specific seizures that can cause lifelong neurological and cognitive disability (Haut et al. 2004). There are three types of ionotropic glutamate receptors (ligand-gated ion channels) named according to their prototypic agonists: $\mathrm{N}$ methyl-D-aspartate (NMDA), 2-amino-3-(3-hydroxy-5-methylisoxazol-4-yl) propanoic acid (AMPA) and kainate (KA). During early stages of postnatal development glutamate receptors of NMDA and AMPA type undergo intensive functional changes owing to modifications in their subunit composition (Carter et al. 1988, Watanabe et al. 1992, Monyer et al. 1994, Wenzel et al. 1997, Sun et al. 1998, Lilliu et al. 2001, Kumar et al. 2002, Matsuda et al. 2002, Wee et al. 2008, Henson et al. 2010, Pachernegg et al. 2012, Paoletti et al. 2013). Participation and role of these receptors in mechanisms of seizures and epilepsy became one of the main targets of intensive investigation (De Sarro et al. 2005, Di Maio et al. 2012, Rektor 2013). $\mathrm{LiCl} /$ Pilocarpine ( $\mathrm{LiCl} / \mathrm{Pilo}$ ) induced status epilepticus is a model of severe seizures resulting in development temporal lobe epilepsy (TLE). This review will consider developmental changes and contribution of NMDA and AMPA receptors in LiCl/Pilo model of status epilepticus in immature rats.

\section{Key words}

Brain • Maturation • Glutamate receptors • Epilepsy

\section{Corresponding author}

E. Szczurowska, Institute of Physiology AS CR, Videňská 1083, CZ 14220 Prague 4, Czech Republic.

E-mail: ewa.szczurowska@epilepsy.biomed.cas.cz

\section{NMDA receptors}

NMDARs are responsible for normal brain development, they are involved in numerous physiological (neuronal growth and migration, memory plasticity) as well as pathological mechanisms (development of epilepsy, neurodegeneration associated with Parkinson, Alzheimer or Huntington diseases). NMDA receptors are ubiquitously distributed throughout the central nervous system (CNS). They are located mainly postsynaptically, but some of them are present on presynaptic membranes where they can play a role of auto- or heteroreceptors (Conti et al. 1997). These receptors can be also found on cortical astrocytes (Lee et al. 2010). NMDARs are heteromeric complexes of four various subunits surrounding central ion channel permeable for calcium. All subunits can be present in a form of different splice variants which exhibit diverse physiological and pharmacological properties. At the moment, seven different NMDA receptor subunits have been determined (NR1, NR2A-D, NR3A and NR3B). Functional NMDA receptors are assembled from at least one (more often two) constitutive, glycine-binding NR1 subunit (there are 8 known isoforms of NR1); one or two NR2A-D glutamate-binding subunits presence of which modulates ion channel functional properties (Monyer et al. 1994, Low and Wee 2010, Traynelis et al. 2010). NR3A-B subunits which do not form functional receptors alone can additionally assemble with NR1-NR2 
complexes and further increase NMDARs functional diversity (Sucher et al. 1995, Wong et al. 2002).

\section{NMDARs subunits and their ontogeny}

During rat ontogeny, especially between postnatal day 7 and 14 (P7 and P14), CNS exhibits increased sensitivity to the toxic effects of glutamate. It has been suggested that the reason for this enhanced vulnerability may be an increased expression of specific NMDA receptor subunits (Miyamoto et al. 2001). Soon after birth cortical neurons exhibit large, long-duration NMDARmediated excitatory postsynaptic currents (EPSCs), but during the first postnatal week EPSCs of the NMDAR becomes shorter and faster (Barth and Malenka 2001, Lu et al. 2001, Liu et al. 2004). These fluctuations in the receptor kinetics are accompanied by the developmental changes in level of expression of specific NMDARs subunits, and their composition varies in different brain regions. Longer currents duration and larger amplitude of EPSCs can be blocked by ifenprodil, a specific antagonist of NMDARs containing NR2B subunit. NR2B dominated currents probably cause greater $\mathrm{Ca}^{2+}$ entry through NMDAR central channel in developing synapses, assisting establishment of thalamocortical circuitry (ConstantinePaton et al. 1998, Cull-Candy et al. 2001). It was shown that the level of expression of NR2A subunit dramatically increases during the first week of postnatal development in rodents, become predominant, and in this way taking over the role of NR2B subunit. Overall levels of NR2B expression do not change dramatically throughout development (Zhong et al. 1995, Stocca and Vicini 1998). Therefore, a change in ratio of the main NMDARs subunits, the synaptic NR2B/NR2A is responsible for the developmental shortening of NMDARs mediated current (Lu et al. 2001).

\section{NMDARs subunits and developmental changes in their expression profiles}

\section{NR1 subunit}

Formation of eight different NR1 splice variants is possible thanks to the insertion or deletion of three short exon cassettes: exon 5 in the $\mathrm{N}$ terminal (N1) and exons 21 and 22 in the $\mathrm{C}$ terminal $(\mathrm{C} 1, \mathrm{C} 2)$ domains of the NR1 molecule (see Fig. 1). NR1-1 is the full-length clone containing both C-terminal exons, NR1-2 lacks exon 21, NR1-3 lacks exon 22, and NR1-4 lacks both, letter (a) indicate presence and letter (b) absence of exon 5 (Durand et al. 1993). These splice variants differ in their spatial and temporal expression patterns, they have also different properties in interaction with protein kinases (Bradley et al. 2006).

In general, NR1 subunits expression begins already at embryonic day 14 (E14), reaches the peak at 3rd postnatal week and then slightly declines towards the adulthood (Laurie et al. 1994, Paupard et al. 1997). The NR1-b variant of NR1 (without the N-terminal N1 exon) is expressed mainly in neonatal sensorimotor cortex, caudate nucleus, and thalamus and CA3 layer in hippocampus, while NR1-a (which contains the N1 exon 5 cassette) is expressed abundantly throughout the brain and is found in all principal cells in hippocampus. Expression of NR1-1 variant is restricted to rostral parts (caudate, hippocampus, cortex) and NR1-4 to more caudal parts (thalamus, cerebellum). Therefore, the composition and number of NMDAR signaling complexes may be dynamically regulated through the splicing of NR1 throughout development (Hollmann and Heinemann 1994, Laurie et al. 1994, Hoffmann et al. 2000).

\section{NR2A subunit}

Determination of regional distribution by means of in situ hybridization analysis (Wenzel et al. 1997, Liu et al. 2004), followed by RT-PCR and then western blotting (Liu et al. 2004) of NR2A and NR2B subunits expression levels have been performed. Results of analysis of different rat and mice brain areas showed that from $\mathrm{P} 0$ to $\mathrm{P} 2$, levels of synthesized $\mathrm{mRNA}$ and protein of NR2A were very low in cerebral cortex and striatum, while in CA1 region of hippocampus expression of mRNA of NR2A subunit at P0 was easily detectable. Expression of NR2A between P5 to P10 increases significantly in the whole brain on both mRNA (see Table 1) and protein levels. It reaches a peak at P12 to P15 and remains at these adult levels (Wenzel et al. 1997, Liu et al. 2004). NR2A levels are the highest in hippocampus, cerebral cortex and thalamus. In hippocampus NR2A mRNA signals are already strong at the time of birth but its protein levels remain low at least up to P10. This delay is caused by posttranscriptional mechanisms which regulate NR2A protein synthesis (Wood et al. 1996, Wenzel et al. 1997).

\section{NR2B subunit}

At birth, NR2B mRNA subunit expression is very strong in cortex and hippocampus while in the 

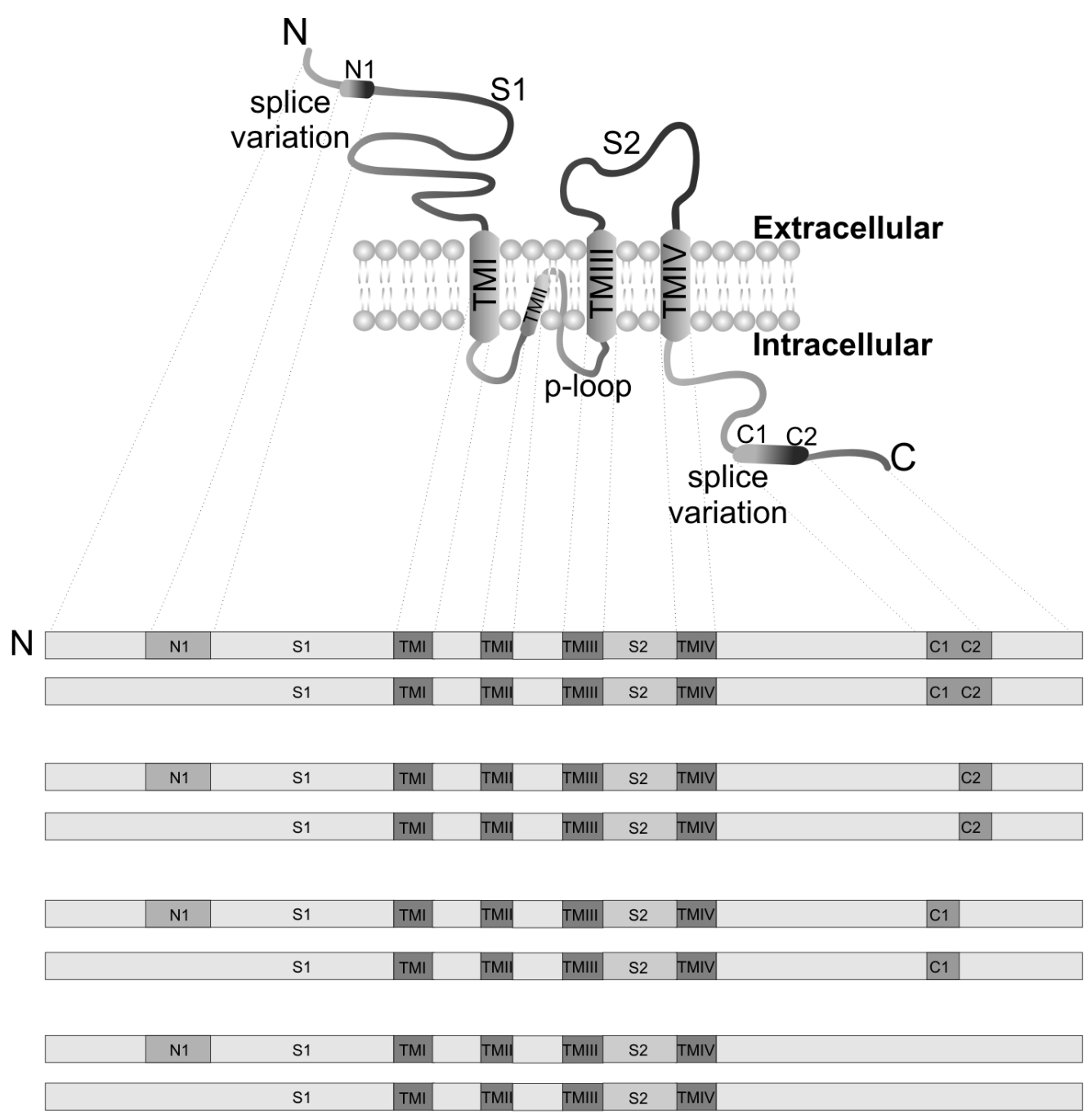

C NR1-1a NR1-1b

Fig. 1. Schematic representation of NR1 subunit structure and its splice variants. TMI-IV transmembrane domains; N1-exon 5 splice variation site; C1 and C2-exons 21 and 22 splice variation sites; S1 and S2-agonist binding domain (NR1-glycine-binding, NR2glutamate-binding, and NR3- glycine-binding) (According to Stephenson et al. 2008)

thalamus, striatum, midbrain, cerebellum, and brainstem expression is moderate or very low. NR2B mRNA levels do not dramatically change since P5, but its protein level increases notably in cerebral cortex and olfactory bulb. At that time, an NR2B mRNA subunit expression level in hippocampus is already high and comparable with the levels in cerebral cortex or olfactory bulb (see Table 1). By P7 to P10, both NR2B mRNA and protein levels increase in whole brain to reach a peak at P21 and then slightly decrease toward adulthood (Wenzel et al. 1997). Marked differences between mRNA and protein levels of NR2B subunit can be explained by the fact that under conditions of low activity, NMDARs are able to stimulate local translation of NR2B subunits (Yashiro et al. 2008, Chen et al. 2007). The gradual decrease in the NMDA mediated EPSCs decay time constant (P1-P16) at thalamocortical synapses in ventroposterior nucleus of the thalamus (VP) have been first reported by Golshani et al. 1998). What might be important in thalamocortical circuitry, a "switch" in synaptic NR2A and NR2B subunits at VP has very similar developmental profile as that in somatosensory cortex (Liu et al. 2004). In general, changes in NR2B/NR2A subunits ratio occurs about two days earlier in VP (P7) than in cortex (P9) (Liu et al. 2004). Timing of this change in hippocampus (even within separate CA regions and dentate gyrus) differs also from other brain structures and occurs at last 7 days later than in thalamus or cortex (Guilarte and McGlothan 1998). In adult hippocampus, NR2B are present at the connections of the perforant path, but usually not detected at mossy fibers synapses (Paoletti et al. 2013). The NR2A and NR2B subunits are the predominant NR2 subunits in the adult hippocampus and neocortex (Monyer et al. 1994, Sheng et al. 1994) and new synapses rich in NR2A are added to those in which predominate NR2B instead of switching subunits (Liu et al. 2004). 


\begin{tabular}{|c|c|c|c|c|c|c|c|}
\hline 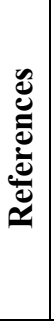 & & 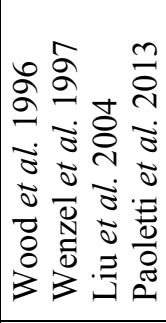 & 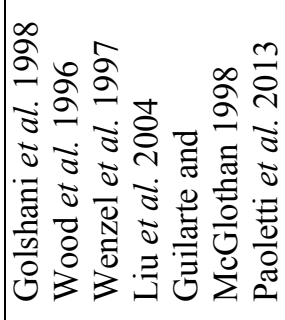 & 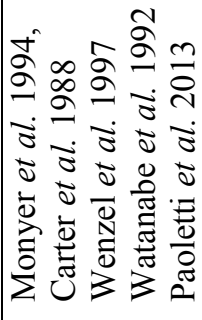 & 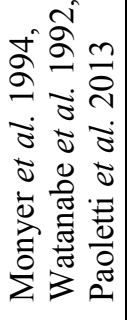 & 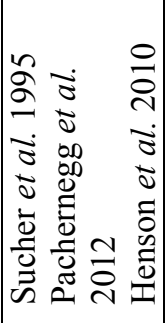 & 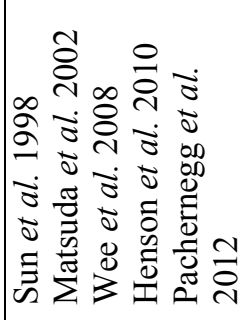 \\
\hline \multirow{4}{*}{$\stackrel{\Xi}{\underline{Z}}$} & Thalamus & $* * * * *$ & $* * *$ & $* * * *$ & $* * * * *$ & - & $* *$ \\
\hline & Hippocampus & $* * * * *$ & $* * *$ & $* * *$ & - & - & $* * * *$ \\
\hline & Neocortex & $* * * * *$ & $* * *$ & $* *$ & $*$ & $*$ & $* * *$ \\
\hline & Whole brain & $* * * * *$ & $* * * *$ & $* * * *$ & $*$ & $*$ & $* * *$ \\
\hline \multirow{4}{*}{ 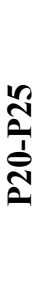 } & Thalamus & $* * * * *$ & $* * *$ & $* * * *$ & $* * * * *$ & $*$ & $*$ \\
\hline & Hippocampus & $* * * * *$ & $* * *$ & $* * *$ & - & - & $* *$ \\
\hline & Neocortex & $* * * * *$ & $* * * *$ & $* *$ & $*$ & $* * *$ & $* *$ \\
\hline & Whole brain & $* * * * *$ & $* * * *$ & $* * * *$ & * & $* *$ & $* * *$ \\
\hline \multirow{4}{*}{$\frac{n}{a}$} & Thalamus & $* * * * *$ & $* * * * *$ & $* * * *$ & $* * * * *$ & $*$ & $*$ \\
\hline & Hippocampus & $* * *$ & $* * * * *$ & $* * *$ & - & - & $*$ \\
\hline & Neocortex & $* * * * *$ & $* * * * *$ & $* *$ & * & $* * * * *$ & $* *$ \\
\hline & Whole brain & $* * * *$ & $* * * * *$ & $* * * *$ & $* *$ & $* * * * *$ & $*$ \\
\hline \multirow{4}{*}{$\frac{\hat{1}}{\hat{L}}$} & Thalamus & $* *$ & $* * * *$ & $* * *$ & $* * * * *$ & $* * * * *$ & - \\
\hline & Hippocampus & $* * * *$ & $* * * * *$ & $* *$ & - & $*$ & - \\
\hline & Neocortex & $* * *$ & $* * * * *$ & $* *$ & $*$ & $* * * * *$ & - \\
\hline & Whole brain & $* * *$ & $* * * * *$ & $* * *$ & $* *$ & $* * * *$ & * \\
\hline \multirow{4}{*}{$\frac{n}{n}$} & Thalamus & $*$ & $* * * *$ & $* * *$ & $* * * *$ & $* * * * *$ & - \\
\hline & Hippocampus & $* *$ & $* * * * *$ & $*$ & * & $*$ & - \\
\hline & Neocortex & $* *$ & $* * * * *$ & $*$ & * & $* * * * *$ & - \\
\hline & Whole brain & $* *$ & $* * * * *$ & $* *$ & $* *$ & $* * * *$ & $*$ \\
\hline \multirow{4}{*}{ 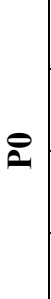 } & Thalamus & $*$ & $* * *$ & $* *$ & $* * *$ & $* * * * *$ & - \\
\hline & Hippocampus & $* *$ & $* * * * *$ & $*$ & $* *$ & - & - \\
\hline & Neocortex & $*$ & $* * * * *$ & $*$ & $* *$ & $* * * * *$ & - \\
\hline & Whole brain & * & $* * * *$ & $* *$ & $* *$ & $* * *$ & - \\
\hline $\begin{array}{l}\text { 竔 } \\
\text { 总 }\end{array}$ & & $\begin{array}{l}\underset{z}{z} \\
z\end{array}$ & $\begin{array}{l}\stackrel{2}{\beth} \\
\stackrel{z}{z}\end{array}$ & $\begin{array}{l}\stackrel{\circlearrowright}{\&} \\
\gtrless\end{array}$ & $\begin{array}{l}\stackrel{\gtrsim}{⿺} \\
\gtrless\end{array}$ & 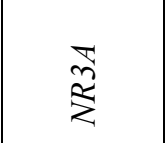 & $\begin{array}{l}\infty \\
\stackrel{2}{2} \\
z\end{array}$ \\
\hline
\end{tabular}


There is general agreement that activity and visual experience increases the NR2A/NR2B ratio at the protein level, (Chen et al. 2007, Yashiro et al. 2008). On the other hand, NR2B-containing receptors may be removed from their localization by several different mechanisms, i.e. (i) involving activity of casein kinase 2 (CK2), (ii) activation of repressor element 1-silencing transcription factor (REST), responsible for long lasting repression of GRIN2B gene transcription, and (iii) activation of metabotropic glutamate receptors group I (mGluRs) which play an important role in the triggering of NMDARs "subunit-switching" (Paoletti et al. 2013). In addition the ratio of NR2A/NR2B subunits can be regulated by means of ubiquitination and subsequent proteasomal degradation (Ehlers 2003, Jurd et al. 2007).

\section{NR2C and NR2D subunit}

NMDA receptors containing NR2C or NR2D subunits are activated by glycine and glutamate with higher potency, showing also lower maximal opening probability and a lower sensitivity to extracellular $\mathrm{Mg}^{2+}$ than receptors containing NR2A or NR2B (Mosley et al. 2010). NR2D-containing NMDA receptors have been hypothesized to exhibit exceptionally slow deactivation following removal of glutamate (Carter et al. 1988, Monyer et al. 1994). These marked differences controlled by a single GluN2 residue in the M3 segment of receptor molecule significantly affect the relative contribution of NMDAR subtypes to synaptic integration and plasticity (Paoletti et al. 2013). NR2D subunits present at the synapse, are co-assembled with other NR2 subunits forming triheteromeric receptors (NR1/NR2B/NR2D) which may not exhibit the slow deactivation of pure NR1/NR2D receptors but may display other NR2D-like properties (Traynelis et al. 1998, Cull-Candy et al. 2001). NR2C and NR2D subunits also show localization patterns distinct from NR2A and NR2B, with prominent expression in cerebellum, discrete nuclei within the basal ganglia and select populations of interneurons (Carter et al. 1988, Monyer et al. 1994). NR2D and NR2C mRNAs are expressed in hippocampal and cortical interneurons but are barely expressed in principal cells (Monyer et al. 1994). NR2C mRNA subunit signals can be already detected at $\mathrm{P} 0$ in cerebellum, but no NR2C protein could be detected even at P10 (Monyer et al. 1994, Watanabe et al. 1994, Wenzel et al. 1997). It has been reported that the late appearance of the NR2C protein coincides with the termination of granule cell migration and the completion of the cerebellar circuitry. On the other hand, the time course of the appearance of NR2C mRNA and protein in the thalamus and olfactory bulb is very similar. NR2C levels increase dramatically during postnatal week 3 , when the mature circuitry is established (Wenzel et al. 1997). NR2D subunit is abundantly expressed in the caudal region of the embryonic brain and its expression decrease rapidly in first two postnatal weeks. During adulthood NR2D expression is low and restricted mostly to mesencephalon and dienencephalon. Both, NR2C and $\mathrm{D}$ are expressed in cortical and hippocampal interneurons but not in principal cells (Watanabe et al. 1992, Monyer et al. 1994, Wenzel et al. 1997).

\section{NR3A and NR3B subunits}

Unlike NR2 subunits, which bind glutamate NR3A form a glycine binding structure (Yao et al. 2008, Henson et al. 2010). NR3A containing receptors exhibit also reduction in $\mathrm{Ca}^{2+}$ permeability, ionic currents, and $\mathrm{Mg}^{2+}$ sensitivity which may be explained by the constriction a ring of threonines present in the external vestibule of the channel (Wada et al. 2006). NR3 subunits assemble into a heterodimers of NR1 and NR3 and a heterotrimeric complex of NR1, NR2, and NR3 subunits that forms an NMDAR with novel properties and attenuated currents compared to NR1/NR2 NMDARs (Henson et al. 2010). NR3A subunit play an important role in preventing the premature synapse formation and NR3A removal allow for the insertion of mature NMDARs that in turn trigger introduction of AMPAR (Sucher et al. 1995). NR3A subunits are expressed at high level already at early stages of development. NR3A mRNA appears in the rat CNS by E16, peaks at second postnatal week and its expression gradually decreases during maturation (Henson et al. 2010, Paoletti et al. 2013). NR3B expression exhibits opposite developmental profile. Its levels are low at early life and progressively increase till adult life (Fukaya et al. 2005, Paoletti et al. 2013).

\section{AMPA receptors}

The AMPA receptors mediate most of the fast excitatory synaptic transmission in the mammalian CNS. Their prolonged activation is highly neurotoxic and plays a key role in generation and spreading of seizure activity. AMPA are heteromeric glutamate receptors consisting of four major subunits: GluR1, 2, 3, and 4 with varying stoichiometries (Sommer et al. 1991, Hollmann and Heinemann 1994). Their diversity is further increased by 
such mechanisms as an alternative splicing or RNA editing which results in formation of the receptors with different biophysical properties of their channels (Lilliu et al. 2001, Kumar et al. 2002). Each of AMPA receptor subunits is encoded by the separated gene and shows unique area- and temporal-expression pattern, therefore AMPA receptor subunits transcripts appear to be independently regulated during development (Lilliu et al. 2001). If an AMPAR lacks a GluR2 subunit, then it will be permeable to sodium, potassium and calcium, but presence of a GluR2 subunit will almost always render the channel calcium impermeable (Hsu et al. 2010). An exonic glutamine (Q) codon in a pore-forming segment of the AMPARs GluR2 subunit protein may be changed to an arginine (R) codon by RNA editing (Sommer et al. 1991). The edited GluR2-containing AMPARs, exhibit outwardly rectifying currents and little $\mathrm{Ca}^{2+}$ permeability, whereas those containing not edited GluR2 generate inwardly rectifying currents and are permeable to $\mathrm{Ca}^{2+}$ ions (Verdoorn et al. 1991, Burnashev et al. 1995). These two forms of GluR2 have been called respectively flip and flop (Standley et al. 1995).

\section{AMPARs and their $\mathrm{Ca}^{2+}$ permeability}

Calcium-permeable AMPARs have been reported to play important role in various physiological and pathological processes (synaptic transmission, plasticity, or neurological diseases including epilepsy) (Washburn et al. 1997, Konig et al. 2001, Cull-Candy et al. 2006, Kwak and Weiss, 2006), and are likely to have important functional implications in developmental (Lawrence and Trussell 2000) and activity-dependent forms of synaptic plasticity (Liu and Cull-Candy 2000). In different cell types of the CNS, AMPARs are functionally and molecularly distinct (see Table 2). The specific expression of rapidly gated, $\mathrm{Ca}^{2+}$ permeable AMPARs in interneurons and relay neurons could be responsible for the shortening of EPSPs and for reduction of the time interval between individual EPSP (Jack and Redman 1971). Calcium entering through AMPARs may activate $\mathrm{Ca}^{2+}$ dependent $\mathrm{K}^{+}$channels and thereby can contribute to the termination of the EPSP (Geiger et al. 1995). Glutamate released from the same presynaptic neuron will exert very different effects on postsynaptic target neurons, depending on the functional and molecular characteristics of the postsynaptic AMPARs. For example AMPAR subunit expression profiles in hippocampal principal neurons (CA3 pyramidal cells, hilar mossy cells) differs from that in interneurons (DG basket cells, hilar interneurons) (Amaral et al. 1990).

In the case of Bergmann glial cells (radial glia, which are present still during adulthood) and DG granule cells, GluR2 and GluR4 transcripts are almost completely edited at the $\mathrm{R} / \mathrm{Q}$ site in most cell types. The low degree of $\mathrm{R} / \mathrm{Q}$ site editing in $\mathrm{DG}$ granule cells is a reason for more rapid desensitization of AMPARs than those in CA3 pyramidal cells or hilar mossy cells. This could be also due to the virtual absence of GluR2 and the high level of GluR4 in Bergmann glial cells (Geiger et al. 1995).

\section{Developmental changes in AMPARs subunits expression}

Low expression levels of AMPARs GluR2 subunit (therefore high $\mathrm{Ca}^{2+}$ permeability) at early stages of CNS development (Durand and Zukin 1993, Monyer et al. 1994) might participate in the increased seizure susceptibility in the immature brain. Increased excitability seems to be caused by $\mathrm{Ca}^{2+}$ permeable AMPARs conducting hyperexcitation and subsequent excitotoxic death of inhibitory GABA-ergic interneurons (Moshé et al. 1983). Additionally, AMPARs lacking GluR2 may still be formed even in the presence of GluR2 mRNA (Greger et al. 2003, Cull-Candy et al. 2006). AMPA receptor subunits are abundantly distributed in the ventral mesencephalon and striatum where they play a crucial role in controlling basal activity and plasticity of both ventral midbrain and striatal neurons. GluR1 and GluR4 mRNAs are expressed at higher levels in mesencephalon than in striatum which develops later during prenatal development (E15-P0) (Lilliu et al. 2001). Immunoreactivity for GluR2/3 subunits is concentrated postsynaptically at corticothalamic synapses and their activation by cortical stimulation results in fast EPSPs and slower NMDA receptor-based EPSPs (Salt and Eaton 1996). The greatest amount of expressed proteins of GluR2 and GluR3 directed to corticothalamic synapses, underlines the role of corticothalamic input in gating sensory transmission through the thalamus (McCormick and Bal 1994, Liu 1997) and in setting up reciprocal thalamocortical oscillations (Liu 1997). During the early stages of life GluR3/4 subunits are broadly expressed in hippocampus. Later in development GluR4 expression decrease in that structure, while GluR2 expression increase and it becomes dominant AMPAR subunit in the adult rat hippocampus. AMPARs density in ventral hippocampus ( $\mathrm{VH})$ is much lower when compared with dorsal hippocampus (DH) due to the lesser 
Table 2. Functional properties and subunit composition of AMPARs in different cell types (according to Geiger et al. 1995).

\begin{tabular}{|c|c|c|c|c|c|c|c|}
\hline \multirow{2}{*}{ Cell type } & \multirow{2}{*}{ 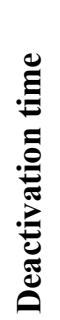 } & \multirow{2}{*}{ 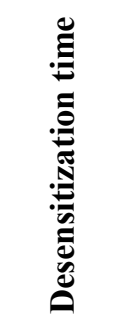 } & \multirow{2}{*}{ 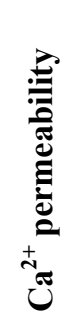 } & \multicolumn{4}{|c|}{ Relative abundance } \\
\hline & & & & GluR1 & GluR2 & GluR3 & GluR4 \\
\hline Neocortex & + & ++++ & $*$ & $*$ & $* * * * *$ & $* *$ & $*$ \\
\hline CA3 pyramidal cells & ++ & +++++ & $*$ & $* * * * *$ & $* * * *$ & $*$ & - \\
\hline Bergman glial cells & + & +++ & $* * *$ & $* * * * *$ & $*$ & $* *$ & $* * *$ \\
\hline$D G$ granule cells & + & ++++ & $*$ & $* * * * *$ & $* * * *$ & $* *$ & - \\
\hline Interneurons DG basket cells & + & ++++ & $* *$ & $* * * * *$ & $* *$ & $* *$ & $* *$ \\
\hline
\end{tabular}

Relative deactivation and desensitization time: + very fast, ++ fast, +++ moderate, ++++ slow, +++++ very slow. Relative expression level and $\mathrm{Ca}^{2+}$ permeability: * very low, $* *$ low, $* * *$ moderate, $* * * *$ high, $* * * * *$ very high, - not detected

expression of the mRNAs of all three AMPAR subunits (Pandis et al. 2006). In rat cortical pyramidal neurons, synaptic AMPARs switch from GluR2-lacking to GluR2containing, occur between P13 and P21 (Kumar et al. 2002), whereas AMPARs on dendrites of the same neurons exhibit characteristics of those GluR2-containing AMPARs, already at P6 till P40 (Brill and Huguenard 2008, Hsu et al. 2010) therefore dendrites of cortical pyramidal neurons at early stages of postnatal development are probably $\mathrm{Ca}^{2+}$ impermeable. The expression of the flop (not edited R/Q i.e. $\mathrm{Ca}^{2+}$ permeable variant) version of GluR1-4 remain constant until P14, whereas the flip variants (edited R/Q i.e. $\mathrm{Ca}^{2+}$ impermeable) are expressed at low levels at birth, and increase considerably between P8 and P14 (Standley et al. 1995). There are also some reports (PellegriniGiampietro et al. 1992) showing that most GluR transcripts are transiently overexpressed, when compared to adult levels, with a peak expression at about P14 in hippocampus (Standley et al. 1995).

\section{NMDARs and AMPARs: general signaling and trafficking}

NMDARs interact with numerous different intracellular signaling pathways by cooperation with several cellular kinases including Protein Kinase A (PKA), Protein Kinase C (PKC), Extracellular signalregulated kinase $1 / 2(E R K 1 / 2)$ or $\mathrm{Ca}^{2+}$ Calmodulindependent Protein Kinase II (CaM II kinase) which directly interact with C-terminal domain of NR2B subunit. The ERK1/2 (extracellular signal-regulated kinase 1/2) signaling pathway is responsible for activation of different transcription factors and plays an important role in synaptic plasticity and cell survival (Sweatt 2004, Thomas and Huganir 2004). It is stimulated (phosphorylated) and differentially regulated by calcium influx through NMDARs, depending on their subunit composition (Sava et al. 2012). In general, activation of ERK is coupled to cellular survival (Hetman and Kharebava, 2006). An excessive NMDAR activation evokes neuronal degeneration by excitotoxic mechanism during early stage of neuronal development (Sava et al. 2012). On the other hand, different pools of NR2Bcontaining NMDA receptors are coupled to ERK in a different way: synaptic receptors are positively coupled, while extrasynaptic NR2B-containing receptors are negatively coupled to ERK. In developing hippocampal neurons, NR2B-containing NMDA receptors have been shown to mediate both pro-death and pro-survival signaling (Martel et al. 2009, Sava et al. 2012).

ERK1/2 pathway involves small GTPase: Ras, which is activated by specific guanine nucleotide exchange factors (GEFs) and inhibited by GTPase activating proteins (GAPs) (Thomas and Huganir 2004). Both RasGEF and RasGAP can directly interact with NR2B subunit of NMDA receptor. Synaptic RasGAP (SynGAP) is present in high concentrations in postsynaptic densities and associate with NMDARs via PSD-95 proteins. The other signaling molecule acting downstream of NMDA receptors is the tyrosine phosphatase: STriatal-Enriched Phosphatase (STEP). Phosphorylation of the serine residue in STEP kinasedomain decreases STEP activity and reduces its affinity 
for substrates. Dephosphorylation of this same serine residue activates STEP. This activation can occur via calcineurin activity promoted by NMDA receptormediated $\mathrm{Ca}^{2+}$ influx. In basal conditions STEP activity is low, but when activated, STEP can down-regulate ERK2 by its dephosphorylation and influence excitotoxicity mediated via NMDARs (Paul et al. 2010). Both phosphorylation and dephosphorylation of ERK2 is $\mathrm{Ca}^{2+}$ influx-dependent. It was reported that induction of large, delayed $\mathrm{Ca}^{2+}$ influx (characteristic for NR2B subunit containing NMDAR) cause dephosphorylation and therefore STEP activation. As a result regulation of activation of the STEP by NR2B can explain NR2B involvement NMDARs in the inhibition of ERK activity (Paul et al. 2010) and influence excitotoxicity mediated via NMDARs (Paul et al. 2010).

Production of functional NMDA receptors is limited, at least in part, by the availability of NR2 subunits (Prybylowski and Wenthold 2004). NMDARs assemble in the endoplasmic reticulum and interact with membrane-associated guanylate kinases (MAGUKs) which are a family of proteins (including SAP102synapse associated protein 102, SAP97 synapse associated protein 97, PSD-93- postsynaptic density protein $93 \mathrm{kDa}$, and PSD-95- postsynaptic density protein $95 \mathrm{kDa}$ ) that play a role in scaffolding of the postsynaptic density (PSD). The NMDAR/MAGUK interaction is mediated by the PDZ-binding domain of the NR2 subunit and Sec8, a protein of the exocyst complex. This interaction is necessary for the delivery of the NMDAR to the synapse. NMDARs are internalized by clathrinmediated endocytosis (McGee and Bredt 2003, Sans et al. 2003). Synaptic and extrasynaptic receptors differ in their subunit composition and are also differentially regulated in response to phosphorylation changes ( $\mathrm{Li}$ et al. 2002). The developmental subunit switch is dependent upon preferential MAGUK binding to either GluN2A or GluN2B subunits (Sans et al. 2003). NR2B-containing receptors delivery to the dendrite is possible thanks to binding of the motor protein KIF17 to a multiprotein complex containing the NR2B (Prybylowski and Wenthold 2004). The extracellular matrix (ECM) protein: reelin modulates NR2B surface diffusion, and reelin overexpression cause decreases in synaptic NR2B expression and reduces NR1/NR2B-mediated synaptic currents (Gladding and Raymond 2011, Groc et al. 2007).

AMPARs undergo kinesin and/or dynein mediated vesicular trafficking in dendrites. The $\mathrm{Ca}^{2+}$ sensitive motor protein, Myosin $\mathrm{Vb}$, is also involved in the dendritic vesicular trafficking of GluA1- containing AMPARs (Henley et al. 2011). Influx of the $\mathrm{Ca}^{2+}$ via activated NMDARs stimulates CaMKII which in turn, phosphorylates GluR1 subunit of AMPARs. MyoVa is $\mathrm{Ca}^{2+}$-activated motor protein, which recognizes and phosphorylated GluR1 connected with Rab11 adaptor complex. Activated by $\mathrm{Ca}^{2+}$ MyoVb transports AMPAR along the actin cytoskeleton to sites of exocytosis. Cytoskeletal adaptor protein 4.1N links AMPARs with actin cytoskeleton. When GluR1A is phosphorylated by PKC at serine 816 and 818 its affinity for $4.1 \mathrm{~N}$ increases and AMPA receptor can be inserted into membrane. On the other hand, phosphorylation of GluR1 at serine 845 by PKA, is responsible for insertion of AMPAR at extrasynaptic and perisynaptic sites where syntaxin 4 mediates membrane fusion events at the sites of exocytosis. Later these receptors are replaced by edited GluR2- containing AMPA receptors (Yang et al. 2008). $\mathrm{PKC}$ isoform protein kinase $\mathrm{M}$ zeta $(\mathrm{PKMz}$ ) (Ling et al. 2002), maintains AMPARs at synapses by downregulating GluR2-containing receptor internalization. RNA editing of GluR2 has been shown to be important for exocytosis (Araki et al. 2010). The signaling of Ras/ER pathway leads to AMPAR insertion into the dendritic membrane up to $3 \mathrm{mM}$ away from the synaptic site of potentiation (Ling et al. 2002, Hoogenraad et al. 2010, Patterson et al. 2010, Henley et al. 2011). In mature neurons NR2A-NMDARs promote Ras/ERK activation as well as surface expression of GluR1 subunit of AMPARs while NR2B-NMDARS inhibit both processes. On the other hand, changes in NR2A or NR2B expression levels and signaling do not markedly influence GluR2 AMPA receptor expression subunit. Loss of GluR1/GluR2 subunits combination mediated by NR2B is rather balanced by the gain in GluR2/GluR3 therefore preventing calcium permeability of AMPARs (Kim et al. 2005). Reversible posttranslational modifications, including phosphorylation, palmitoylation and ubiquitination, have been shown to control various aspects of AMPA receptor trafficking and functional modulation (Lu et al. 2012).

\section{Ictogenic and anticonvulsant action of drugs influencing NMDA and AMPA receptors}

Agonists of NMDA receptors (NMDA, homocysteic acid) elicit epileptic seizures. Their efficacy is high at early stages of development and decreases with age (Mareš and Velíšek 1992, Mareš et al. 1997a). Similar but not so marked attenuation of efficacy during 
maturation was observed with the anticonvulsant action of some antagonists of NMDA receptors and their anticonvulsant action (Velíšek et al. 1990, 1991, Mikolášová et al. 1994, Kubová and Mareš 1995). Ifenprodil, a selective antagonist for NR2B subunitcontaining NMDA receptors, exhibits anticonvulsant action only during the first three postnatal weeks in rats (Mareš and Mikulecká 2009). Antagonists of AMPA receptors CNQX, DNQX and NBQX have only moderate anticonvulsant action against pentetrazol-induced seizures expressed during the first three postnatal weeks (Velíšek et al. 1995). NBQX but not noncompetitive antagonist of AMPA receptors GYKI52466 exhibited decreasing action against cortical epileptic afterdischarges during development (Kubová et al. 1997, Mareš et al. 1997b).

\section{Status epilepticus in immature brain}

The incidence of status epilepticus (SE) is highest in patients during the first and after the 60th year of life (Haut et al. 2004). High incidence of status epilepticus in infants and children might be due to immaturity of mechanisms arresting seizures, what was demonstrated in amygdala-induced afterdischarges (Moshé and Albala 1983) as well as in hippocampal afterdischarges (Velíšek and Mareš 1991) in rats. There is little information concerning effects of convulsive generalized SE on the immature brain due to a high mortality mainly as a result of respiratory failure after long lasting tonic-clonic seizures (Haut et al. 2004). Therefore several animal models of SE with long-lasting clonic seizures and low mortality were developed (BenAri 1985, Turski et al. 1986, Pitkanen et al. 2002). A great variability of the results has been reported in animal models of SE induced by chemoconvulsants such as lithium-pilocarpine model (LiCl/Pilo).

\section{Mechanism of lithium-pilocarpine model}

Mechanism of action of pilocarpine in induction of SE depends on activation of M1 muscarinic receptor leading to subsequent stimulation of NMDA receptors. Activation of ERK1/2 (MAP kinase-mitogen-activated protein kinases) triggered by phospholipase $\mathrm{C}$ (PLC)dependent IP3 release occurs independently to $\mathrm{Ca}^{2+}$ mediated oxidative stress. IP3-mediated surge in intracellular $\mathrm{Ca}^{2+}$ and its increased influx through NMDARs leads to activation of NOX (NADPH oxidase) and generation of superoxide. It results in oxidative modification of cell surface NMDARs with impairment of receptor function. Mentioned events may trigger pathological states that lead to the local activation of neuronal nitric oxide synthase (nNOS) in close association with the NMDA receptor, and NADPH oxidase. Thus, $\mathrm{Ca}^{2+}$ influx through NMDAR channels leads to production of superoxide via NOX activation, and $\mathrm{Ca}^{2+}$ uptake by mitochondria in combination with NO production triggers cell death (Di Maio et al. 2011).

It was repeatedly demonstrated that young animals are more sensitive to epileptogenic stimuli as well as to development of epilepsy, but resulting brain injury differs from that observed in mature animals (Cavalheiro et al. 1987, Lado et al. 2002, Kubova et al. 2004). Status epilepticus can be induced by LiCl/Pilo administration in rats since the second postnatal week, which (when compared to human development) is considered as a newborn/infant/toddler (Haut et al. 2004). Previous study shows that the LiCl/Pilo elicited SE at early developmental stage (e.g. at P12) induce plastic changes and have long lasting structural and functional consequences (Nairismagi et al. 2006).

\section{Early changes after LiCl/Pilo induced status epilepticus}

Li/Pilo induced status epilepticus including its acute, silent and of recurrent seizures phase is a very complicated process difficult to study in detail. Application of pilocarpine triggers a long lasting cascade of changes including alterations of ionic gradient across the cell membrane, activation of different types of kinases, modification of gene expression, activation of trophic factors, enzymes etc. Due to its complexity and involvement of huge scale of factors here we will focus on changes occurring mostly during the acute phase of pilocarpine model (Scorza et al. 2009).

\section{Involvement of NMDARs in SE}

Due to the well characterized neuronal damage, synaptic reorganization, well determined morphological and biochemical changes as well as an easy access, most of the research concerning developmental changes in NMDARs subunits expression pattern were focused on hippocampal formation (Haut et al. 2004). In hippocampal area mRNA levels of NMDARs subunits change dynamically during development. In models of epilepsy most marked changes in hippocampal mRNA levels occur during transition from the latent phase to chronic limbic seizures. The area of maximal hippocampal neuronal injury after lithium-pilocarpine induced SE in the immature brain (P20) is ventral 
hippocampus (VH) what is consistent with previous records from the mature brain (Ekstrand et al. 2011). Proper function of the mitochondrial electron transport system relies on disulfide oxidation or reduction (Di Maio et al. 2012). Thiol residues (functional side groups in cysteine) are important in regulation of signal transduction cascades, protein import, and regulation of the activity of transcription factors. Impairment of antioxidant systems causes a redox imbalance and reduction of thiol residues in neuronal proteins. In in vitro pilocarpine-induced epileptic activity, Reactive Oxygen Species (ROS) production cause NMDA-mediated oxidative injury leading to apoptosis.

In the $\mathrm{LiCl} /$ Pilo model of $\mathrm{SE}$ induction, IP3 synthesis is necessary for activation of two independent pathways, which together cause abnormal NMDAR subunit expression: $\mathrm{Ca}^{2+}$-dependent NADPH oxidase activation and ERK1/2 phosphorylation. These pathways are together responsible for short-term up-regulation (overexpression) of the NR2B subunit in vitro and in vivo. Short-term exposure to pilocarpine induces early overexpression of functional NR2B subunits in hippocampal neuronal cultures, while no changes in the expression of NR2A subunit were detected after $24 \mathrm{~h}$ of exposure to pilocarpine (Di Maio et al. 2011). On the other hand, later after Pilo application NR2B subunits can regulate NR2A subunits expression level in two ways: by hyperactivation of NR2B, which is induced via ERK1/2 activation or, independently by oxidative stress-mediated NR2B overexpression. It was reported that NR2A but not NR2B subunit containing NMDARs activation was required for development of limbic epilepsy in kindling and pilocarpine models (Chen et al. 2007). Several investigators (Kubova et al. 2001, 2002, Wasterlain et al. 2002, Nairismagi et al. 2006) described in detail morphological changes occurring in different brain structures after LiCl/Pilo-induced SE in immature brain. In TLE NR2B containing NMDARs are restored in adult brain, so neuronal hyperexcitability in epilepsy may be caused by mechanisms similar to those during early development, a stage of high susceptibility to epileptogenesis (Di Maio et al. 2011). On the other hand proteolysis of NR2B subunit by calpain was observed in hippocampus in animals after SE (Araujo et al. 2005). Susceptibility of the NMDA receptor cleavage by calpain varies within neonatal period (Dong et al. 2006).

\section{Involvement of AMPARs in SE}

Seizures can cause rapid alterations in AMPAR subunit composition and function (mediated by trafficking and endocytosis) in the developing brain. Hyperexcitability of hippocampal networks may cause their transition from normal to epileptic networks. GluR2 subunit expression and therefore the $\mathrm{Ca}^{2+}$-permeability of AMPARs changes in various seizure models. There is an increase in AMPA-mediated calcium permeability associated with an augmented AMPAR-mediated potentiation of hippocampal epileptiform activity (Sanchez et al. 2001). It is possible that this hyperexcitability is a consequence of a decrease in GABAergic inhibition induced by $\mathrm{Ca}^{2+}$ activated phosphatase, calcineurin $\mathrm{C}(\mathrm{CaN})$. The expression levels of GluR2 changes during two weeks following SE and prior to the development of spontaneous seizures which begin at 1.5 months following SE in this model (Roch et al. 2002, Raol et al. 2003). Northern blot analysis and in situ hybridization showed that 6 and $12 \mathrm{~h}$ after LiCl/Piloinduced status epilepticus the mRNA level of some subunits of AMPA-selective glutamate receptors dramatically change (Condorelli et al. 1994). In the dentate gyrus an increase of GluR3 mRNA level is induced $12 \mathrm{~h}$ after LiCl/Pilo treatment, while a clear decrease in GluR1 mRNA level and no significant change in GluR2 mRNA level can be observed in the same area (Condorelli et al. 1994). Both the GluR1 decrease and the GluR3 increase are temporary and a return to basal level after 48-72 h. In the CA1 subfield of the hippocampus 12-24 $\mathrm{h}$ after SE, an analogous decrease in GluR-1 and GluR-3 expression levels occurred, but at $48 \mathrm{~h}$ the expression return to control values. Thetre was also observed a general decrease in mRNA level for the AMPA receptor subunits (GluR-1-3) in the hippocampal layers, in particular in CA3 and CA4 subfields (Condorelli et al. 2004). Grooms et al. (2000) and $\mathrm{Hu}$ et al. (2012) found a marked decrease in GluR2 and GluR1expression 12-16 $\mathrm{h}$ after SE. Consequently the reduction in GluR2 might serve as a "molecular switch", leading to the arrangement of $\mathrm{Ca}^{2+}$ permeable AMPA receptors and enhancing the toxicity of endogenous glutamate following a neurological insult ( $\mathrm{Hu}$ et al. 2012). Calcium ions influx mediate the rapid increase in the activity of CaMKII, PKA (Protein Kinase A), and PKC (Protein Kinase C) in the hippocampal neurons, this may lead to enhanced phosphorylation of the GluR1 and GluR2 receptor subunits. Phosphorylation of GluR1 subunit immediately after seizures enhances AMPARmediated EPSCs, as well as phosphorylation of GluR2 that promote internalization from the synaptic surface and 
cause decrease in GluR2. Additionally, inhibition of $Q / R$ editing in GluR2 results in increased excitability of hippocampal neurons with associated spontaneous seizures (Krestel et al. 2004).

The seizure induced expression of $\mathrm{Ca}^{2+}$ permeable AMPAR is developmentally regulated and indicates the susceptibility of the immature brain to epileptic activity (Cull-Candy et al. 2006). There is an increase in GluR2 mRNA in mature dentate gyrus neurons (DGNs) after SE, suggesting a decrease in $\mathrm{Ca}^{2+}$ permeability, which may be neuroprotective against excitotoxic injury (Liu et al. 2004, Porter et al. 2006). Interestingly, $3 \mathrm{~h}$ after SE in the whole brain of immature animals the subunit composition of AMPARs changes from predominantly GluR3/4 subunits to predominantly GluR2/3 subunits (Hu et al. 2012). For that reason it can be proposed that developing hippocampus has the ability to activate the endogenous anti-epileptic mechanism (to maintain the balance between excitation and inhibition) after SE, and consequently reduce brain damage. These findings raise the possibility that DGNs could be utilized therapeutically as a naïve population of cells to potentially inhibit epileptogenesis after SE (Porter et al. 2006). The increased expression of GluR2 can inhibit excessive $\mathrm{Ca}^{2+}$ influx and protect hippocampal neurons from excitotoxic death, conferring early but transient protection in the immature brain after SE (Rakhade et al. 2008, Hu et al. 2012).

\section{Concluding remarks}

Early upregulation of NR2B subunit may be involved in the induction and maintenance of epileptogenesis, since NR1/NR2B heterodimers are primarily expressed as facilitatory presynaptic autoreceptors on hippocampal neurons and promote NR2A overexpression (Woodhall et al. 2001, Di Maio et al. 2012). Ifenprodil, a highly specific NR2B antagonist is able to moderately block thiol oxidation in rat hippocampus and hippocampal neurons, it was also able to block NR2A overexpression, one of the major events coupled with BDNF (Brain Derived Neurotrophic Factor) expression implicated in the development of chronic epilepsy and mossy fiber sprouting. On the other hand ifenprodil treatment was not able to avoid the activation of caspase 3 and cell death occurring after pilocarpine SE, and did not display neuroprotection against pilocarpine treatment. In contrast, noncompetitive NMDA antagonist MK 801 can block thiol oxidation, apoptosis and cell death. For that reason NR2B subunit is not utterly involved in NMDAR-induced cell damage in both in vitro and in vivo pilocarpine model of SE (Choo 2012, Di Maio et al. 2011). It has proposed that the location of NMDA receptors influences whether they are coupled to pro-death or pro-survival signals: synaptic NMDA receptors are neuroprotective, whereas extrasynaptic receptors preferentially promote cell death pathways (Hardingham and Bading 2010). The diverse localization of different NR2 subunits increases the possibility that subunit-selective antagonists and allosteric modulators or their appropriate combination, might provide beneficial antiepileptic treatments (Mosley et al. 2010). Therefore the investigation concerning development of antiepileptic treatment should also be turned in direction of the signaling processes regulating overexpression of mentioned NMDARs subunits. Targeting of early events following SE insult including IP3 synthesis or ROS generation might also be advantageous.

Phosphorylation of the intracellular C-terminus of NR3A (by PKA, PKC, protein tyrosine kinase PTK, or CaMKII) could play critical roles in regulating NR3A trafficking, signaling, and channel properties (Sucher et al. 1995, Eriksson et al. 2002, Chen and Roche 2007). Due to the fact, that NR3A-containing NMDARs subunit have reduced $\mathrm{Ca}^{2+}$ permeability (Sucher et al. 1995, Henson et al. 2010, Pachernegg et al. 2012) it has been suggested that NR3A subunit plays a neuroprotective role early in development (Nakanishi et al. 2009). Increasing NR3A subunit expression level in epileptic brain can be an interesting option.

AMPAR antagonists are highly potent anticonvulsants (e.g. topiramate, talampanel), widely used in seizure models (Traynelis et al. 2010, Rakhade and Jensen 2009). But AMPARs undergo also developmental changes in their subunit composition. Calcium permeable (not containing GluR2) AMPARs are highly expressed in the somatosensory cortex in immature brain (Hsu et al. 2009, 2010). $\mathrm{Ca}^{2+}$ is an important intracellular signaling molecule; therefore it has been hypothesized that the regulation of the expression of AMPA receptor subunits might participate e.g. in neuronal injury after seizures (Standley et al. 1995).

Taken together, these specific developmental changes in NMDA and AMPARs subunit composition and expression patterns, as well as their involvement in intracellular signaling, represent promising targets for development of highly age-specific therapeutics that influence excitotoxicity and subsequent neuronal damage. 


\section{Conflict of Interest}

There is no conflict of interest.

\section{Acknowledgements}

Supported by grants: GAUK 200 107, GAUK 102107

\section{References}

AMARAL DG, ISHIZUKA N, CLAIBORNE B: Neurons, numbers and the hippocampal network. Progr Brain Res 83: 1-11, 1990.

ARAÚJO IM, XAPELli S, GIL JM, MOHAPEL P, PETERSÉN A, PINHEIRO PS, MALVA JO, BAHR BA, BRUNDIN P, CARVALHO CM: Proteolysis of NR2B by calpain in the hippocampus of epileptic rats. Neuroreport 16: 393-396, 2005.

BARTH AL, MALENKA RC: NMDAR EPSC kinetics do not regulate the critical period for LTP at thalamocortical synapses. Nature Neurosci 4: 235-236, 2001.

BEN ARI Y: Limbic seizure and brain damage produced by kainic acid - mechanisms and relevance to human temporal lobe epilepsy. Neuroscience 14: 375-403, 1985.

BRADLEY J, CARTER SR, RAO VR, WANG J, FINKBEINER S: Splice variants of the NR1 subunit differentially induce NMDA receptor-dependent gene expression. J Neurosci 26: 1065-1076, 2006.

BRILL J, HUGUENARD JR: Sequential changes in AMPA receptor targeting in the developing neocortical excitatory circuit. J Neurosci 28: 13918-13928, 2008.

BURNASHEV N, ZHOU Z, NEHER E, SAKMANN B: Fractional calcium currents through recombinant GluR channels of the NMDA, AMPA and kainate receptor subtypes. $J$ Physiol 485: 403-418, 1995.

CARTER C, BENAVIDES J, LEGENDRE P, VINCENT JD, NOEL F, THURET F, LLOYD KG, ARBILLA S, ZIVKOVIC B, MACKENZIE ET, SCATTON B, LANGER SZ: Ifenprodil and S1-82.0715 as cerebral antiischemic agents. 2. Evidence for N-methyl-D-aspartate receptor antagonist properties. J Pharmacol Exp Ther 247: 1222-1232, 1988.

CAVALHEIRO EA, SILVA DF, TURSKI WA, CALDERAZZO-FILHO LS, BORTOLOTTO ZA, TURSKI L: The susceptibility of rats to pilocarpine-induced seizures is age-dependent. Brain Res 465: 43-58, 1987.

CHEN Q, HE S, HU XL, YU J, ZHOU Y, ZHENG J, ZHANG S, ZHANG C, DUAN WH, XIONG ZQ: Differential roles of NR2A- and NR2B-containing NMDA receptors in activity-dependent brain-derived neurotrophic factor gene regulation and limbic epileptogenesis. J Neurosci 27: 542-552, 2007.

CHOI DW: Glutamate neurotoxicity and diseases of the nervous system. Neuron 1: 623-634, 1988.

CHOO AM: NR2A and NR2B subunits differentially mediate MAP kinase signaling and mitochondrial morphology following excitotoxic insult. Neurochem Internat 60: 506-516, 2012.

CONDORELLI DF, BELLUARDO N, MUDO G, DELL'ALBANI P, JIANG X, GIUFFRIDA-STELLA AM: Changes in gene-expression of AMPA-selective glutamate receptor subunits induced by status epilepticus in rat brain. Neurochem Int 25: 367-376, 1994.

CONSTANTINE-PATON M, CLINE HT: LTP and activity-dependent synaptogenesis: the more alike they are, the more different they become. Curr Opin Neurobiol 8: 139-148, 1998.

CONTI F, MINELLI A, DEBIASI S, MELONE M: Neuronal and glial localization of NMDA receptors in the cerebral cortex. Mol Neurobiol 14: 1-18, 1997.

CULL-CANDY S, BRICKLEY S, FARRANT M: NMDA receptor subunits: diversity, development and disease. Curr Opin Neurobiol 11: 327-335, 2001.

CULL-CANDY S, KELLY L, FARRANT M: Regulation of $\mathrm{Ca}^{2+}$-permeable AMPA receptors: synaptic plasticity and beyond. Curr Opin Neurobiol 16: 288-297, 2006.

De SARRO G, GITTO R, RUSSO E, IBBADU GF, BARRECA ML, DE LUCA L, CHIMIRRI A: AMPA receptor antagonists as potential anticonvulsant drugs. Curr Top Med Chem 5: 31-42, 2005.

Di MAIO R, MASTROBERARDINO PG, HU X, MONTERO L, GREENAMYRE JT: Pilocapine alters NMDA receptor expression and function in hippocampal neurons: NADPH oxidase and ERK1/2 mechanisms. Neurobiol Dis 42: 482-495, 2011. 
DI MAIO R, MASTROBERARDINO PG, HU X, MONTERO LM, GREENAMYRE JT: Thiol oxidation and altered NR2B/NMDA receptor functions in in vitro and in vivo pilocarpine models: implications for epileptogenesis. Neurobiol Dis 49: 87-98, 2012.

DINGLEDINE R, BORGES K, BOWIE D, TRAYNELIS SF: The glutamate receptor ion channels. Pharmacol Rev 51: 7-61, 1999.

DONG YN, WU HY, HSU FC, COULTER DA, LYNCH DR: Developmental and cell-selective variations in Nmethyl-D-aspartate receptor degradation by calpain. J Neurochem 99: 206-217, 2006.

DURAND GM, ZUKIN RS: Developmental regulation of messenger-RNAs encoding rat-brain kainate/AMPA receptors: a northern analysis study. J Neurochem 61: 2239-2246, 1993.

EHLERS MD: Activity level controls postsynaptic composition and signaling via the ubiquitin-proteasome system. Nat Rev Neurosc 6: 231-242, 2003.

EKSTRAND JJ, POULIOT W, SCHEERLINCK P, DUDEK FE: Lithium pilocarpine-induced status epilepticus in postnatal day 20 rats results in greater neuronal injury in ventral versus dorsal hippocampus. Neuroscience 192: 699-707, 2011.

ERIKSSON M, NILSSON A, FROELICH-FABRE S, AKESSON E, DUNKER J, SEIGER A, FOLKESSON R, BENEDIKZ E, SUNDSTRÖM E: Cloning and expression of the human N-methyl-D-aspartate receptor subunit NR3A. Neurosci Lett 321: 177-181, 2002.

FUKAYA M, HAYASHI Y, WATANABE M: 1NR2 to NR3B subunit switchover of NMDA receptors in early postnatal motoneurons. Eur J Neurosci 21: 1432-1436, 2005.

GEIGER JR, MELCHER T, KOH DS, SAKMANN B, SEEBURG PH, JONAS P, MONYER H: Relative abundance of subunit mRNAs determines gating and $\mathrm{Ca} 2+$ permeability of AMPA receptors in principal neurons and interneurons in rat CNS. Neuron 15: 193-204, 1995.

GLADDING CM, RAYMOND LA: Mechanisms underlying NMDA receptor synaptic/extrasynaptic distribution and function. Mol Cell Neurosci 48: 308-320, 2011.

GOLSHANI P, WARREN RA, JONES EG: Progression of change in NMDA, non-NMDA, and metabotropic glutamate receptor function at the developing corticothalamic synapse. J Neurophysiol 80: 143-154, 1998.

GROC L, CHOQUET D, STEPHENSON FA, VERRIER D, MANZONI OJ, CHAVIS P: NMDA receptor surface trafficking and synaptic subunit composition are developmentally regulated by the extracellular matrix protein Reelin. J Neurosci 27: 10165-10175, 2007.

GROOMS SY, OPITZ T, BENNETT MVL, ZUKIN RS: Status epilepticus decreases glutamate receptor 2 mRNA and protein expression in hippocampal pyramidal cells before neuronal death. Proc Nat Acad Sci USA 97: 3631$3636,2000$.

GUILARTE TR, MCGLOTHAN JL: Hippocampal NMDA receptor mRNA undergoes subunit specific changes during developmental lead exposure. Brain Res 790: 98-107, 1998.

HARDINGHAM GE, BADING H: Synaptic versus extrasynaptic NMDA receptor signalling: implications for neurodegenerative disorders. Nat Rev Neurosci 11: 682-696, 2010.

HAUT SR, VELISKOVA J, MOSHE SL: Susceptibility of immature and adult brains to seizure effects. Lancet Neurology 3: 608-617, 2004.

HENLEY JM, BARKER EA, GLEBOV OO: Routes, destinations and delays: recent advances in AMPA receptor trafficking. Trends in Neurosci 34: 258-268, 2011.

HENSON MA, ROBERTS AC, PÉREZ-OTAÑO I, PHILPOT BD: Influence of the NR3A subunit on NMDA receptor functions. Prog Neurobiol 91: 23-37, 2010.

HETMAN M, KHAREBAVA G: Survival signaling pathways activated by NMDA receptors. Curr Top Med Chem 6: 787-799, 2006.

HOFFMANN H, GREMME T, HATT H, GOTTMANN K: Synaptic activity-dependent developmental regulation of NMDA receptor subunit expression in cultured neocortical neurons. J Neurochem 75: 1590-1599, 2000.

HOLLMANN M, HEINEMANN S: Cloned glutamate receptors. Annu Rev Neurosci 17: 31-108, 1994. 
HOOGENRAAD CC, POPA I, FUTAI K, MARTINEZ-SANCHEZ E, WULF PS, VAN VLIJMEN T, DORTLAND BR, OORSCHOT V, GOVERS R, MONTI M, HECK AJ, SHENG M, KLUMPERMAN J, REHMANN H, JAARSMA D, KAPITEIN LC, VAN DER SLUIJS P: Neuron specific Rab4 effector GRASP-1 coordinates membrane specialization and maturation of recycling endosomes. PLoS Biol 8: e1000283, 2010.

HSU CI, WANG TC, HOU SYT, CHIN TY, CHANG YC: Quantitative study of the developmental changes in calcium-permeable AMPA receptor-expressing neurons in the rat somatosensory cortex. J Comp Neurol 518: 75-91, 2010.

HU NW, ONDREJCAK T, ROWAN MJ: Glutamate receptors in preclinical research on Alzheimer's disease: update on recent advances. Pharmacol Biochem Behav 100: 855-862, 2012.

JACK JJ, REDMAN SJ: An electrical description of the motoneurone, and its application to the analysis of synaptic potentials. J Physiol 215: 321-352, 1971.

JURD R, THORNTON C, WANG J, LUONG K, PHAMLUONG K, KHARAZIA V, GIBB SL, RON D: Mind bomb-2 is an E3 ligase that ubiquitinates the N-methyl-D-aspartate receptor NR2B subunit in a phosphorylationdependent manner. J Biol Chem 283: 301-310, 2008.

KONIG N, POLUCH S, ESTABEL J, DURAND M, DRIAN MJ, EXBRAYAT JM: Synaptic and non-synaptic AMPA receptors permeable to calcium. Jap J Pharmacol 86: 1-17, 2001.

KRESTEL HE, SHIMSHEK DR, JENSEN V, NEVIAN T, KIM J, GENG Y, BAST T, DEPAULIS A, SCHONIG K, SCHWENK F, BUJARD H, HVALBY Ø, SPRENGEL R, SEEBURG PH: A genetic switch for epilepsy in adult mice. $J$ Neurosci 24: 10568-10578, 2004.

KUBOVÁ H, MAREŠ P: Suppression of cortical epileptic afterdischarges by ketamine is not stable during ontogenesis in rats. Pharmacol Biochem Behav 52: 489-492, 1995.

KUBOVÁ H, VILÁGI I, MIKULECKÁ A, MAREŠ P: NonNMDA antagonist GYKI 52466 suppresses cortical afterdischarges in immature rats. Eur J Pharmacol 333: 17-26, 1997.

KUBOVA H, DRUGA R, LUKASIUK K, SUCHOMELOVÁ L, HAUGVICOVÁ R, JIRMANOVÁ I, PITKÄNEN A: Status epilepticus causes necrotic damage in the mediodorsal nucleus of the thalamus in immature rats. J Neurosci 21: 3593-3599, 2001.

KUBOVA H, DRUGA R, HAUGVICOVA R, SUCHOMELOVA L, PITKÄNEN A: Dynamic changes of status epilepticus-induced neuronal degeneration in the mediodorsal nucleus of the thalamus during postnatal development of the rat. Epilepsia 43: 54-60, 2002.

KUBOVA H, MARES P, SUCHOMELOVA L, BROZEK G, DRUGA R, PITKANEN A: Status epilepticus in immature rats leads to behavioural and cognitive impairment and epileptogenesis. Eur J Neurosci 19: 32553265, 2004.

KUMAR SS, BACCI A, KHARAZIA V, HUGUENARD JR: A developmental switch of AMPA receptor subunits in neocortical pyramidal neurons. J Neurosci 22: 3005-3015, 2002.

KWAK S, WEISS JH: Calcium-permeable AMPA channels in neurodegenerative disease and ischemia. Curr Opin Neurobiol 16: 281-287, 2006.

LADO FA, LAURETA EC, MOSHÉ SL: Seizure-induced hippocampal damage in the mature and immature brain. Epileptic Disord 4: 83-97, 2002.

LAURIE DJ, SEEBURG PH: Regional and developmental heterogeneity in splicing of the rat brain NMDAR1 mRNA. J Neurosci 14: 3180-3194, 1994.

LAWRENCE JJ, TRUSSELL LO: Long-term specification of AMPA receptor properties after synapse formation. J Neurosci 20: 4864-4870, 2000.

LEE M-C, TING KK, ADAMS S, BREW BJ, CHUNG R, GUILLEMIN GJ: Characterisation of the expression of NMDA receptors in human astrocytes. Plos One 5: e14123, 2010.

LI B, CHEN N, LUO T, OTSU Y, MURPHY TH, RAYMOND LA: Differential regulation of synaptic and extrasynaptic NMDA receptors. Nat Neurosci 5: 833-834, 2002.

LILLIU V, PERNAS-ALONSO R, TRELLES RD, DI PORZIO U, ZUDDAS A, PERRONE-CAPANO C: Ontogeny of AMPA receptor gene expression in the developing rat midbrain and striatum. Mol Brain Res 96: 133-141, 2001. 
LING DS, BENARDO LS, SERRANO PA, BLACE N, KELLY MT, CRARY JF, SACKTOR TC: Protein kinase Mzeta is necessary and sufficient for LTP maintenance. Nat Neurosci 5: 295-296, 2002.

LIU SQJ, CULL-CANDY SG: Synaptic activity at calcium-permeable AMPA receptors induces a switch in receptor subtype. Nature 405: 454-458, 2000.

LIU XB: Subcellular distribution of AMPA and NMDA receptor subunit immunoreactivity in ventral posterior and reticular nuclei of rat and cat thalamus. J Comp Neurol 388: 587-602, 1997.

LIU XB, MURRAY KD, JONES EG: Switching of NMDA receptor 2A and 2B subunits at thalamic and cortical synapses during early postnatal development. J Neurosci 24: 8885-8895, 2004.

LOW CM, WEE KSL: New insights into the not-so-new NR3 subunits of N-methyl-D-aspartate receptor: localization, structure, and function. Mol Pharmacol 78: 1-11, 2010.

LU KT, SUN CL, WO PY, YEN HH, TANG TH, NG MC, HUANG ML, YANG YL: Hippocampal neurogenesis after traumatic brain injury is mediated by vascular endothelial growth factor receptor-2 and the Raf/MEK/ERK cascade. J Neurotrauma 28: 441-450, 2011.

LU W, ROCHE KW: Posttranslational regulation of AMPA receptor trafficking and function. Curr Opin Neurobiol 22: 470-479, 2012.

MAREŠ P, MIKULECKÁ A: Different effects of two NMDA receptor antagonists on seizures, spontaneous behavior and motor performance in immature rats. Epilepsy Behav 14: 32-39, 2009.

MAREŠ P, VELÍŠEK L: N-methyl-D-aspartate (NMDA)-induced seizures in developing rats. Develop Brain Res 65 : 185-189, 1992.

MAREŠ P, FOLBERGROVÁ J, LANGMEIER M, HAUGVICOVÁ R, KUBOVÁ H: Convulsant action of D,Lhomocysteic acid and its stereoisomers in immature rats. Epilepsia 38: 767-776, 1997a.

MAREŠ P, MIKULECKÁ A, POMETLOVÁ M: Anticonvulsant action of NBQX in immature rats: comparison with the effects on motor performance. J Pharmacol Exp Ther 281: 1120-1126, $1997 \mathrm{~b}$.

MARTEL MA, WYLLIE DJ, HARDINGHAM GE: In developing hippocampal neurons, NR2B-containing N-methylD-aspartate receptors (NMDARs) can mediate signaling to neuronal survival and synaptic potentiation, as well as neuronal death. Neuroscience 158: 334-343, 2009.

MATSUDA K, KAMIYA Y, MATSUDA S, YUZAKI M: Cloning and characterization of a novel NMDA receptor subunit NR3B: a dominant subunit that reduces calcium permeability. Mol Brain Res 100: 43-52, 2002.

MCCORMICK DA, BAL T: Sensory gating mechanisms of the thalamus. Curr Opin Neurobiol 4: 550-556, 1994.

MCGEE AW, BREDT DS: Assembly and plasticity of the glutamatergic postsynaptic specialization. Curr Opin Neurobiol 13: 111-118, 2003.

MIKOLÁŠOVÁ R, VELÍŠEK L, VORLÍČEK J, MAREŠ P: Developmental changes of ketamine action against epileptic afterdischarges induced by hippocampal stimulation in rats. Develop Brain Res 81: 105-112, 1994.

MIYAMOTO K, NAKANISHI H, MORIGUCHI S, FUKUYAMA N, ETO K, WAKAMIYA J, MURAO K, ARIMURA K, OSAME M: Involvement of enhanced sensitivity of N-methyl-D-aspartate receptors in vulnerability of developing cortical neurons to methylmercury neurotoxicity. Brain Res 901: 252-258, 2001.

MONYER H, BURNASHEV N, LAURIE DJ, SAKMANN B, SEEBURG PH: Developmental and regional expression in the rat brain and functional properties of four NMDA receptors. Neuron 12: 529-540, 1994.

MOSHÉ SL, ALBALA BJ: Maturational changes in postictal refractoriness and seizure susceptibility in developing rats. Ann Neurol 13: 552-557, 1983.

MOSHÉ SL, ALBALA BJ, ACKERMANN RF, ENGEL J Jr: Increased seizure susceptibility of the immature brain. Brain Res 283: 81-85, 1983.

MOSLEY CA, ACKER TM, HANSEN KB, MULLASSERIL P, ANDERSEN KT, LE P, VELLANO KM, BRÄUNER-OSBORNE H, LIOTTA DC, TRAYNELIS SF: Quinazolin-4-one derivatives: a novel class of non-competitive NR2C/D subunit-selective N-methyl-D-aspartate receptor antagonists. J Med Chem 12: 54765490, 2010.

NAIRISMAGI J, PITKANEN A, KETTUNEN MI, KAUPPINEN RA, KUBOVA H: Status epilepticus in 12-day-old rats leads to temporal lobe neurodegeneration and volume reduction: a histologic and MRI study. Epilepsia 47: 479-488, 2006. 
NAKANISHI N, TU S, SHIN Y, CUI J, KUROKAWA T, ZHANG D, CHEN HS, TONG G, LIPTON SA: Neuroprotection by the NR3A subunit of the NMDA receptor. $J$ Neurosci 29: 5260-5265, 2009.

PACHERNEGG S, STRUTZ-SEEBOHM N, HOLLMANN M: GluN3 subunit containing NMDA receptors: not just one-trick ponies. Trends Neurosci 35: 240-249, 2012.

PANDIS C, SOTIRIOU E, KOUVARAS E, ASPRODINI E, PAPATHEODOROPOULOS C, ANGELATOU F: Differential expression of NMDA and AMPA receptor subunits in rat dorsal and ventral hippocampus. Neuroscience 140: 163-175, 2006.

PAOLETTI P, BELLONE C, ZHOU Q: NMDA receptor subunit diversity: impact on receptor properties, synaptic plasticity and disease. Nat Rev Neurosc 14: 383-400, 2013.

PATTERSON MA, SZATMARI EM, YASUDA R: AMPA receptors are exocytosed in stimulated spines and adjacent dendrites in a Ras-ERK-dependent manner during long-term potentiation. Proc Natl Acad Sci U.S.A. 107: 15951-15956, 2010.

PAUL S, CONNOR JA: NR2B-NMDA receptor-mediated increases in intracellular $\mathrm{Ca}^{2+}$ concentration regulate the tyrosine phosphatase, STEP, and ERK MAP kinase signaling. J Neurochem 114: 1107-1118, 2010.

PAUPARD MC, FRIEDMAN LK, ZUKIN RS: Developmental regulation and cell-specific expression of N-methyl-Daspartate receptor splice variants in rat hippocampus. Neuroscience 79: 399-409, 1997.

PELLEGRINI-GIAMPIETRO DE, ZUKIN RS, BENNETT MVL, CHO SH, PULSINELLI WA: Switch in glutamate receptor subunit gene-expression in CA1 subfield of hippocampus following global-ischemia in rats. Proc Natl Acad Sci U.S.A. 89: 10499-10503, 1992.

PITKANEN A, NISSINEN J, NAIRISMAGI J, LUKASIUK K, GRÖHN OH, MIETTINEN R, KAUPPINEN R: Progression of neuronal damage after status epilepticus and during spontaneous seizures in a rat model of temporal lobe epilepsy. Prog Brain Res 135: 67-83, 2002.

PORTER BE, CUI XN, BROOKS-KAYAL AR: Status epilepticus differentially alters AMPA and kainate receptor subunit expression in mature and immature dentate granule neurons. Eur J Neurosci 23: 2857-2863, 2006.

PRYBYLOWSKI K, WENTHOLD RJ: $N$-methyl-D-aspartate receptors: subunit assembly and trafficking to the synapse. J Biol Chem 279: 9673-9676, 2004.

RAKHADE SN, JENSEN FE: Epileptogenesis in the immature brain: emerging mechanisms. Nat Rev Neurol 5: 380391, 2009.

RAKHADE SN, ZHOU C, AUJLA PK, FISHMAN R, SUCHER NJ, JENSEN FE: Early alterations of AMPA receptors mediate synaptic potentiation induced by neonatal seizures. $J$ Neurosci 28: 7979-7990, 2008.

RAOL YSH, BUDRECK EC, BROOKS-KAYAL AR: Epilepsy after early-life seizures can be independent of hippocampal injury. Ann Neurol 53: 503-511, 2003.

REKTOR I: Perampanel, a novel, non-competitive, selective AMPA receptor antagonist as adjunctive therapy for treatment-resistant partial-onset seizures. Expert Opin Pharmacother 14: 225-235, 2013.

ROCH C, LEROY C, NEHLIG A, NAMER IJ: Predictive value of cortical injury for the development of temporal lobe epilepsy in 21-day-old rats: an MRI approach using the lithium-pilocarpine model. Epilepsia 43: 1129-1136, 2002.

SALT TE, EATON SA: Functions of ionotropic and metabotropic glutamate receptors in sensory transmission in the mammalian thalamus. Progr Neurobiol 48: 55-72, 1996.

SANCHEZ RM, KOH S, RIO C, WANG C, LAMPERTI ED, SHARMA D, CORFAS G, JENSEN FE: Decreased glutamate receptor 2 expression and enhanced epileptogenesis in immature rat hippocampus after perinatal hypoxia-induced seizures. J Neurosci 21: 8154-8163, 2001.

SANS N, PRYBYLOWSKI K, PETRALIA RS, CHANG K, WANG YX, RACCA C, VICINI S, WENTHOLD RJ: NMDA receptor trafficking through an interaction between PDZ proteins and the exocyst complex. Nat Cell Biol 5: 520-530, 2003.

SAVA A: NMDA-induced ERK signaling is mediated by NR2B subunit in rat cortical neurons and switches from positive to negative depending on stage of development Neuropharmacology 62: 925-932, 2012.

SCORZA FA, ARIDA RM, NAFFAH-MAZZACORATTI MG, SCERNI DA, CALDERAZZO L, CAVALHEIRO EA: The pilocarpine model of epilepsy: what have we learned? An Acad Bras Cienc 81: 345-365, 2009. 
SHENG M, CUMMINGS J, ROLDAN LA, JAN YN, JAN LY: Changing subunit composition of heteromeric NMDA receptors during development of rat cortex m1. Nature 368: 144-147, 1994.

SOMMER B, KOHLER M, SPRENGEL R, SEEBURG PH: RNA editing in brain controls a determinant of ion flow in glutamate-gated channels. Cell 67: 11-19, 1991.

STANDLEY S, TOCCO G, TOURIGNY MF, MASSICOTTE G, THOMPSON RF, BAUDRY M: Developmental changes in alpha-amino-3-hydroxy-5-methyl-4-isoxazole propionate receptor properties and expression in the rat hippocampal formation. Neuroscience 67: 881-892, 1995.

STEPHENSON FA, COUSINS SL, KENNY AV: Assembly and forward trafficking of NMDA receptors (Review). Mol Membr Biol 25: 311-320, 2008.

STOCCA G, VICINI S: Increased contribution of NR2A subunit to synaptic NMDA receptors in developing rat cortical neurons. J Physiol (Lond) 507: 13-24, 1998.

SUCHER NJ, AKBARIAN S, CHI CL, LECLERC CL, AWOBULUYI M, DEITCHER DL, WU MK, YUAN JP, JONES EG, LIPTON SA: Developmental and regional expression pattern of a novel NMDA receptor-like subunit (NMDAR-L) in the rodent brain. $J$ Neurosci 15: 6509-6520, 1995.

SUN L, MARGOLIS FL, SHIPLEY MT, LIDOW MS: Identification of a long variant of mRNA encoding the NR3 subunit of the NMDA receptor: its regional distribution and developmental expression in the rat brain. FEBS Lett 441: 392-396, 1998.

SWEATT JD: Mitogen-activated protein kinase in synaptic plasticityand memory. Curr Opin Neurobiol 14: 311-317, 2004.

THOMAS GM, HUGANIR RL: MAPK cascade signaling and synaptic plasticity. Nature Rev Neurosci 5: 173-183, 2004.

TRAYNELIS SF, BURGESS MF, ZHENG F, LYUBOSLAVSKY P, POWERS JL: Control of voltage-independent zinc inhibition of NMDA receptors by the NR1 subunit. $J$ Neurosci 18: 6163-6175, 1998.

TRAYNELIS SF, WOLLMUTH LP, MCBAIN CJ, MENNITI FS, VANCE KM, OGDEN KK, HANSEN KB, YUAN H, MYERS SJ, DINGLEDINE R: Glutamate receptor ion channels: structure, regulation, and function. Pharmacol Rev 62: 405-496, 2010.

TURSKI L, CAVALHEIRO EA, SIEKLUCKA DZIUBA M, IKONOMIDOU TURSKI C, CZUCZWAR SJ, TURSKI WA: Seizures produced by pilocarpine - neuropathological sequelae and activity of glutamate-decarboxylase in the rat forebrain. Brain Res 398: 37-48, 1986.

VELÍŠEK L, MAREŠ P: Increased epileptogenesis in the immature hippocampus. Exp Brain Res (Suppl) 20: 183-185, 1991.

VELÍŠEK L, KUSÁ R, KULOVANÁ M, MAREŠ P: Excitatory amino acid antagonists and pentylenetetrazol-induced seizures during ontogenesis: 1. The effects of 2-amino-7-phosphonoheptanoate. Life Sci 46: 1349-1357, 1990.

VELÍŠEK L, VEREŠOVÁ S, POBIŠOVÁ H, MAREŠ P: Excitatory amino acid antagonists and pentylenetetrazolinduced seizures during ontogenesis. 2. The effects of MK-801. Psychopharmacology 14: 510-514, 1991.

VELÍŠEK L, KUBOVÁ H, MAREŠ P, VACHOVÁ D: Kainate/AMPA receptor antagonists are anticonvulsant against the tonic hindlimb component of pentylenetetrazol-induced seizures in developing rats. Pharmacol Biochem Behav 51: 153-158, 1995.

VERDOORN TA, BURNASHEV N, MONYER H, SEEBURG PH, SAKMANN B: Structural determinants of ion flow through recombinant glutamate receptor channels. Science 252: 1715-1718, 1991.

WADA A, TAKAHASHI H, LIPTON SA, CHEN HS: NR3A modulates the outer vestibule of the "NMDA" receptor channel. J Neurosci 26: 13156-13166, 2006.

WASHBURN MS, NUMBERGER M, ZHANG S, DINGLEDINE R: Differential dependence on GluR2 expression of three characteristic features of AMPA receptors. $J$ Neurosci 17: 9393-9406, 1997.

WASTERLAIN CG, NIQUET J, THOMPSON KW, BALDWIN R, LIU H, SANKAR R, MAZARATI AM, NAYLOR D, KATSUMORI H, SUCHOMELOVA L, SHIRASAKA Y: Seizure-induced neuronal death in the immature brain. Do seizures damage the brain? Prog Brain Res 135: 335-353, 2002.

WATANABE M, INOUE Y, SAKIMURA K, MISHINA M: Developmental changes in distribution of NMDA-receptor channel subunit mRNAs. Neuroreport 3: 1138-1140, 1992. 
WATANABE M, MISHINA M, INOUE Y: Distinct spatiotemporal expressions of five NMDA receptor channel subunit mRNAs in the cerebellum. J Comp Neurol 343: 513-519, 1994.

WEE KS, ZHANG Y, KHANNA S, LOW CM: Immunolocalization of NMDA receptor subun it NR3B in selected structures in the rat forebrain, cerebellum, and lumbar spinal cord. J Comp Neurol 509: 118-135, 2008.

WENZEL A, FRITSCHY JM, MOHLER H, BENKE D: NMDA receptor heterogeneity during postnatal development of the rat brain: differential expression of the NR2A, NR2B, and NR2C subunit proteins. $J$ Neurochem $\mathbf{6 8}$ : 469-478, 1997.

WONG HK, LIU XB, MATOS MF, CHAN SF, PÉREZ-OTAÑO I, BOYSEN M, CUI J, NAKANISHI N, TRIMMER JS, JONES EG, LIPTON SA, SUCHER NJ: Temporal and regional expression of NMDA receptor subunit NR3A in the mammalian brain. J Comp Neurol 450: 303-317, 2002.

WOOD MW, VANDONGEN HMA, VANDONGEN AMJ: The 5'-untranslated region of the N-methyl-D-aspartate receptor NR2A subunit controls efficiency of translation1. J Biol Chem 271: 8115-8120, 1996.

WOODHALL G, EVANS DI, CUNNINGHAM MO, JONES RSG: NR2B-containing NMDA autoreceptors at synapses on entorhinal cortical neurons. J Neurophysiol 86: 1644-1651, 2001.

YANG Y, WANG XB, FRERKING M, ZHOU Q: Delivery of AMPA receptors to perisynaptic sites precedes the full expression of long-term potentiation. Proc Natl Acad Sci USA 105: 11388-11393, 2008.

YASHIRO K, PHILPOT B: Regulation of NMDA receptor subunit expression and its implications for LTD, LTP, and metaplasticity $J$ Neuropharm 55: 1081-1094, 2008.

ZHONG J, CARROZZA DP, WILLIAMS K, PRITCHETT DB, MOLINOFF PB: Expression of messenger-RNAs encoding subunits of the NMDA receptor in developing rat brain. J Neurochem 64: 531-539, 1995. 